\title{
Antioxidant pathways are up-regulated during biological nitrogen fixation to prevent ROS-induced nitrogenase inhibition in Gluconacetobacter diazotrophicus
}

\author{
Sylvia M. C. Alquéres - Jose Henrique M. Oliveira $\cdot$ Eduardo M. Nogueira \\ Helma V. Guedes $\cdot$ Pedro L. Oliveira $\cdot$ Fernando Câmara $\cdot$ Jose I. Baldani • \\ Orlando B. Martins
}

Received: 25 March 2010/Revised: 17 June 2010/Accepted: 19 July 2010/Published online: 10 August 2010 (C) The Author(s) 2010. This article is published with open access at Springerlink.com

\begin{abstract}
Gluconacetobacter diazotrophicus, an endophyte isolated from sugarcane, is a strict aerobe that fixates $\mathrm{N}_{2}$. This process is catalyzed by nitrogenase and requires copious amounts of ATP. Nitrogenase activity is extremely sensitive to inhibition by oxygen and reactive oxygen species (ROS). However, the elevated oxidative metabolic rates required to sustain biological nitrogen fixation (BNF) may favor an increased production of ROS. Here, we explored this paradox and observed that ROS levels are, in fact, decreased in nitrogen-fixing cells due to the up-regulation of transcript levels of six ROS-detoxifying genes. A cluster analyses based on common expression patterns revealed the existence of a stable cluster with $99.8 \%$ similarity made up of the genes encoding the $\alpha$-subunit of nitrogenase Mo-Fe protein (nifD), superoxide dismutase
\end{abstract}

Communicated by Stuart Ferguson.

S. M. C. Alquéres $(\bowtie) \cdot$ J. H. M. Oliveira ·

P. L. Oliveira · O. B. Martins

Laboratório de Biologia Molecular,

Instituto de Bioquímica Médica,

Universidade Federal do Rio de Janeiro,

Rio de Janeiro, RJ CEP 21941-590, Brazil

e-mail: alqueres@bioqmed.ufrj.br

E. M. Nogueira

Depto de Genética e Biologia Molecular,

Universidade Federal do Estado do Rio de Janeiro,

Rio de Janeiro, RJ, Brazil

H. V. Guedes · J. I. Baldani

Laboratório de Genética e Bioquímica,

Embrapa Agrobiologia, Seropédica, RJ, Brazil

F. Câmara

Instituto Microbiologia Prof. Paulo de Góes.,

Universidade Federal do Rio de Janeiro,

Rio de Janeiro, RJ, Brazil $(\operatorname{sod} A)$ and catalase type E $(k a t E)$. Finally, nitrogenase activity was inhibited in a dose-dependent manner by paraquat, a redox cycler that increases cellular ROS levels. Our data revealed that ROS can strongly inhibit nitrogenase activity, and G. diazotrophicus alters its redox metabolism during BNF by increasing antioxidant transcript levels resulting in a lower ROS generation. We suggest that careful controlled ROS production during this critical phase is an adaptive mechanism to allow nitrogen fixation.

Keywords Gluconacetobacter diazotrophicus . Biological nitrogen fixation - Reactive oxygen species . Nitrogenase

\section{Introduction}

Sugarcane production in many countries depends on the traditional practice of adding nitrogen $\left(\mathrm{NH}_{3}\right)$ fertilizer for optimum growth and yield. In regions of the world where nitrogen input is very low, the diazotrophic bacterium Gluconacetobacter diazotrophicus has often been isolated from surface-sterilized roots, stems and leaves (Baldani et al. 1997; Cavalcante and Dobereiner 1988). Studies trying to understand the importance of $G$. diazotrophicus in plants grown under these conditions showed that in a Ndeficient environment, sugarcane plants inoculated with the strain PA15 grew better and had a higher total $\mathrm{N}$ content than plants inoculated with the mutant nif- or uninoculated plants (Sevilla et al. 2001). These results indicate that the transfer of fixed $\mathrm{N}$ from $G$. diazotrophicus to sugarcane might be a significant mechanism to support plant growth.

BNF is the process by which $\mathrm{N}_{2}$ is converted into $\mathrm{NH}_{3}$ and is considered an energy-demanding process because it consumes 16 mol of ATP per mol of $\mathrm{N}_{2}$ (Kim and Rees 
1994). This energy requirement can be met by aerobic respiration (Flores-Encarnacion et al. 1999). In this process, energy-rich substrates (nutrients) are oxidized, donating its electrons to a series of membrane proteins, known as the electron transport chain (ETC.), which will conserve the energy of the electron flow in the form of a membrane potential that will be the driving force to allow ATP synthesis. During respiration, molecular oxygen is the final electron acceptor, receiving 4 electrons, being reduced to water. However, some electrons may escape from the ETC., giving rise to partially reduced oxygen intermediates, commonly called reactive oxygen species (ROS) (Kowaltowski et al. 2009). Despite the need of high-energy supplies to support BNF, which is only achieved by respiration, nitrogenase is notoriously sensitive to oxygen and ROS (Robson and Postgate 1980).

So far, studies concerning the effects of oxygen on $G$. diazotrophicus have mainly dealt with the nature of its respiratory system. The most accepted hypothesis, called "respiratory protection", postulates that the increase in $\mathrm{O}_{2}$ consumption during BNF would allow sufficient ATP production and at the same time lower intracellular oxygen levels, preserving nitrogenase activity (Dalton and Postgate 1968; Flores-Encarnación et al. 1999; Pan and Vessey 2001; Ureta and Nordlund 2002). Less data have been acquired concerning the influence of increased respiration on the production and detoxification of reactive oxygen species (ROS), a natural by-product of aerobic metabolism and its effects on BNF. The generation of partially reduced forms of oxygen (i.e. ROS), such as superoxide radical $\left(\mathrm{O}_{2}^{-}\right)$and hydrogen peroxide $\left(\mathrm{H}_{2} \mathrm{O}_{2}\right)$, may be part of the $\mathrm{O}_{2}$ toxicity problem in nitrogen-fixing organisms (Dalton 1995). Considering the lack of information about free radical biology during $\mathrm{BNF}$ and the importance of this process for sustainable agriculture, the aim of our work is to investigate the influence of ROS production and detoxification in $G$. diazotrophicus. Our data revealed that, besides the respiratory protection mechanism, G. diazotrophicus alters its redox metabolism during BNF by increasing antioxidant transcript levels resulting in a decreased ROS generation that is critical to sustain nitrogenase activity and allow BNF. As we show that ROS can strongly inhibit the BNF process, we suggest that careful control of ROS production during this critical phase is an adaptive mechanism to allow nitrogen fixation.

\section{Materials and methods}

Cultivation conditions

Gluconacetobacter diazotrophicus strain PAL5 (BR11281) was obtained from the Embrapa Agrobiologia Culture
Collection and was grown in LGI-P medium on a shaker with gentle agitation $(100 \mathrm{rpm})$ for $48 \mathrm{~h}$ at $30^{\circ} \mathrm{C}$. After three successive rounds of cultivation, cells were harvested by centrifugation at $12,000 \mathrm{~g}$ for $2 \mathrm{~min}$ and resuspended in LGI-P medium $\left(0.2 \mathrm{~g} / 1 \mathrm{~K}_{2} \mathrm{HPO}_{4}, 0.6 \mathrm{~g} / 1 \mathrm{KH}_{2} \mathrm{PO}_{4}, 0.2 \mathrm{~g} / 1\right.$ $\mathrm{MgSO}_{4} \cdot 7 \mathrm{H}_{2} \mathrm{O}, 0.02 \mathrm{~g} / 1 \mathrm{CaCl}_{2} \cdot 2 \mathrm{H}_{2} \mathrm{O}, 0.002 \mathrm{~g} / 1 \mathrm{Na}_{2} \mathrm{MoO}_{4}$. $2 \mathrm{H}_{2} \mathrm{O}, 0.01 \mathrm{~g} / \mathrm{l} \mathrm{FeCl}_{3} \cdot 6 \mathrm{H}_{2} \mathrm{O}, 100 \mathrm{~g} / \mathrm{l}$ sacarose) with $1.0 \mathrm{mM}$ of $\left(\mathrm{NH}_{4}\right)_{2} \mathrm{SO}_{4}$ to yield an $\mathrm{A}_{600}$ of 0.6. Aliquots $(1 \mathrm{ml})$ of cell suspensions were transferred into $250 \mathrm{ml}$ flasks containing $50 \mathrm{ml}$ of the fresh LGI-P medium (supplemented with $1.0 \mathrm{mM}$ (nitrogen-fixing condition) or $20 \mathrm{mM}$ of $\left(\mathrm{NH}_{4}\right)_{2} \mathrm{SO}_{4}$ (non-nitrogen-fixing condition) then incubated at $30^{\circ} \mathrm{C}$ with agitation $(100 \mathrm{rpm})$.

The resistance of $G$. diazotrophicus cells to oxidative stress was investigated by the addition of Paraquat (PQ), a superoxide generator (Hassett et al. 1987) to a final concentration of 0.5 or $5 \mathrm{mM}$ in fixing and non-nitrogen-fixing cultures after $24 \mathrm{~h}$ cultivation.

\section{Determination of ROS production in G. diazotrophicus}

Free-radical production was assessed by fluorescence microscopy of cells from liquid cultures grown in LGI-P medium under fixing and non-nitrogen-fixing conditions. G. diazotrophicus cultures were threefold concentrated and incubated for $10 \mathrm{~min}$ in the presence of the redox-sensitive dye CM- $\mathrm{H}_{2}$ DCFDA (5 $\left.\mu \mathrm{M}\right)$ (Invitrogen-Molecular probes), followed by a washing step with fresh media and direct visualization (without fixative agents) of the samples. Images were acquired on a Zeiss Axioskop microscope with an Axiocam MRC5 using a Zeiss-09 filter set (excitation-BP 450-490; beam splitter-FT 510; emissionLP 515). Magnification was set at $630 \times$.

\section{Catalase activity}

G. diazotrophicus was assayed for catalase activity according to (Aebi 1984). Briefly, crude extracts were incubated in Tris-buffer $\mathrm{pH} 7.0$ in the presence of $9 \mathrm{mM}$ hydrogen peroxide $\left(\mathrm{H}_{2} \mathrm{O}_{2}\right)$ and absorbance was monitored at $240 \mathrm{~nm}$ for $1 \mathrm{~min}$. The amount of protein was determined according to Bradford (1976).

Quantitative real-time polymerase chain reaction (qPCR)

The expression of selected genes was determined by realtime qPCR with SYBR Green Supermix (Applied Biosystems) using iCycler thermal cycler (Applied Biosystems). RNA was isolated with Trizol according to the manufacturer's protocol. Samples were treated with DNase I (Invitrogen). Total RNA $(2.5 \mu \mathrm{g})$ was used for cDNA synthesis with the Superscript First-strand synthesis kit 
(Invitrogen). cDNA was purified using MinElute PCR purification kit (Qiagen) and used as qPCR templates. Each PCR reaction contained $12.5 \mu \mathrm{l}$ of $2 \times \mathrm{SYBR}$ Green $\mathrm{Su}-$ permix (Applied Biosystems), $1 \mu \mathrm{M}$ primers and appropriate templates in a $25-\mu \mathrm{l}$ reaction. PCR reactions were heated to $95^{\circ} \mathrm{C}$ for $3 \mathrm{~min}$ and then for 40 cycles with steps of $95^{\circ} \mathrm{C}$ for $30 \mathrm{~s}, 60^{\circ} \mathrm{C}$ for $15 \mathrm{~s}, 60^{\circ} \mathrm{C}$ for $45 \mathrm{~s}$. The generation of specific PCR products was confirmed by the melting curve analysis and gel electrophoresis. The $2^{-\Delta \Delta \mathrm{Ct}}$ method (Livak and Schmittgen 2001) was employed for relative quantification and $23 \mathrm{~S}$ rDNA was the housekeeping gene control. The results were based on the average of triplicate experiments. Primer sequences are available upon request.

\section{Cluster analysis}

We used qPCR to measure mRNA levels of cells grown under fixing or non-fixing conditions at 18, 24, 36, 48 and $72 \mathrm{~h}$. The expressions of $\operatorname{sodA}, \mathrm{kat} E$, kat, katC, gorA, gorB and nifD were measured at the same time points and the cluster analysis was also carried out at these times. Genes were grouped on the basis of their common expression patterns across the time points and different conditions.

Cluster analysis of gene expression was carried out with the MINITAB v.14 package, using Euclidian distances and the Ward method for linkage. The single, complete, average, centroid or median linkage methods displayed the same results in the test.

\section{Nitrogenase activity}

For the in vivo nitrogenase assay, $2 \mathrm{ml}$ of $G$. diazotrophicus-saturated culture grown in LGI-P medium was used to inoculate $250-\mathrm{ml}$ flasks containing $48 \mathrm{ml}$ LGI-P supplemented with $1 \mathrm{mM}$ of $\left(\mathrm{NH}_{4}\right)_{2} \mathrm{SO}_{4}$. The cells were grown in a shaking water bath at $100 \mathrm{rpm}$ for the indicated time at $30^{\circ} \mathrm{C}$. The nitrogenase activity was determined in whole cells by the acetylene reduction method as described (Reis and Dobereiner 1998). Ethylene produced was analyzed by gas chromatography in a Perkin Elmer gas chromatograph equipped with a flame ionization detector and Porapak $\mathrm{N}$ column. The protein content was determined by the Bradford method (Bradford 1976).

\section{Results}

ROS levels are decreased during nitrogen fixation

To test our hypothesis that redox metabolism is altered during the BNF process, we evaluated the presence of oxygen radicals in $G$. diazotrophicus. Cells were stimulated to fix nitrogen and compared to a non-nitrogen-fixing condition. These two groups were loaded in the presence of the redox-sensitive fluorescent dye and observed under the microscope. Figure 1 shows that nitrogen-fixing cells (FIX - in Fig. 1) present a decreased fluorescent signal (1B and 1D), an indicative of lower ROS levels, when compared to non-nitrogen-fixing cells (NFIX) (1F and $1 \mathrm{H})$, both at 24 and $48 \mathrm{~h}$ incubation time.

These results demonstrate that cellular ROS are reduced when $G$. diazotrophicus is fixing nitrogen, pointing to a possible inverse correlation between the presence of ROS and nitrogenase activity. Furthermore, it is evident the nonfixing cells inhabit an environment where ROS is part of the cellular milieu without exhibiting any noticeable adverse effect. This is consistent with the notion that ROS act as physiological molecules in a diverse set of biological situations (Forman et al. 2010; Terada 2006), as it seems to occur in non-fixing $G$. diazotrophicus. It is tempting to speculate why ROS levels have to be reduced during BNF and we hypothesized that the sensitivity of nitrogenase to inhibition by oxygen intermediates may be in the center of this question.

\section{ROS detoxification is up-regulated during BNF process}

In order to investigate the mechanisms involved in the decrease of ROS during BNF, we first measured catalase activity, an antioxidant enzyme involved in $\mathrm{H}_{2} \mathrm{O}_{2}$ removal. Figure 2 a shows increased activity in nitrogen-fixing cultures at 48 and $72 \mathrm{~h}$. Considering that catalase activity was increased up to sixfold in fixing cells and at the same time ROS levels were greatly reduced (Fig. 1), we hypothesized that other antioxidant pathways may also be active during BNF. Genes that could possibly be involved in ROS detoxification were identified in the recently published $G$. diazotrophicus genome (Bertalan et al. 2009). Our analysis revealed the presence of six genes whose products are directly involved in ROS removal (Table 1).

qPCR used to measure mRNA levels of the identified ROS-detoxification genes in PAL-5 strain grown in high (NFIX) or low-nitrogen (FIX) media showed a strong induction of $\operatorname{sodA}$, katE, kat, katC and gorA genes in response to nitrogen limitation (Fig. 2b). Importantly, genes that are not related to ROS metabolism (GSglutamine synthetase-and amidase) do not have their expression levels altered during nitrogen fixation (Fig. 2b). Our results demonstrated a specific response of cells to reduce ROS levels under BNF conditions. Consistent with data presented in Fig. 1, non-fixing cultures seems to live in the presence of ROS and this condition does not represent a challenge since all the antioxidant enzymes analyzed were present in basal levels compared to fixing cells. 

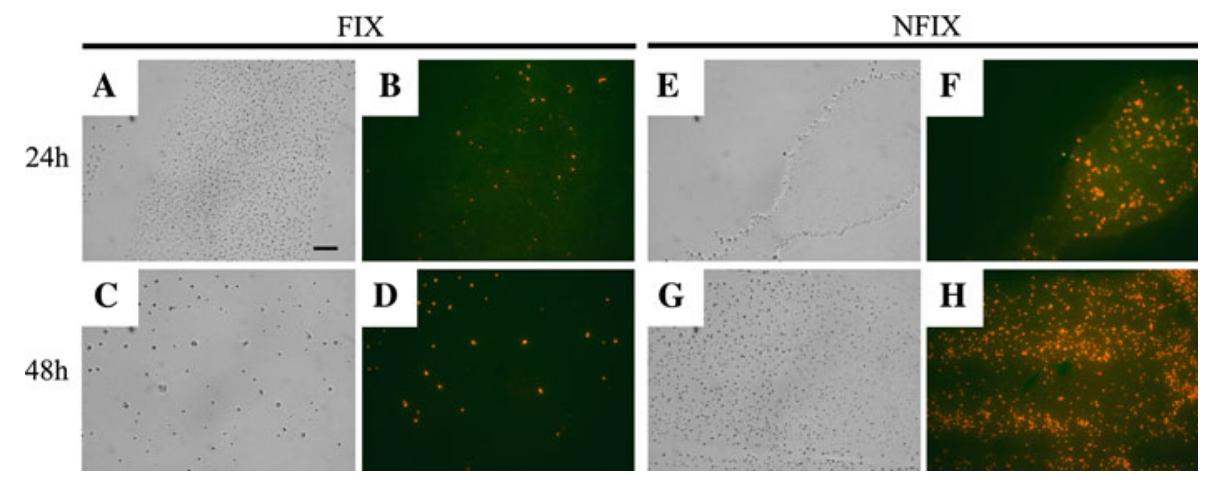

Fig. 1 ROS levels are decreased in nitrogen-fixing cells. G. diazotrophicus grown under fixing $(F I X)$ and non-fixing $(N F I X)$ conditions were stained with $\mathrm{CM}-\mathrm{H}_{2}$ DCFDA, sensitive to ROS. a, c, e and $\mathbf{g}$ represent bright field images. $\mathbf{b}, \mathbf{d}, \mathbf{f}, \mathbf{h}$ are the fluorescent images, an
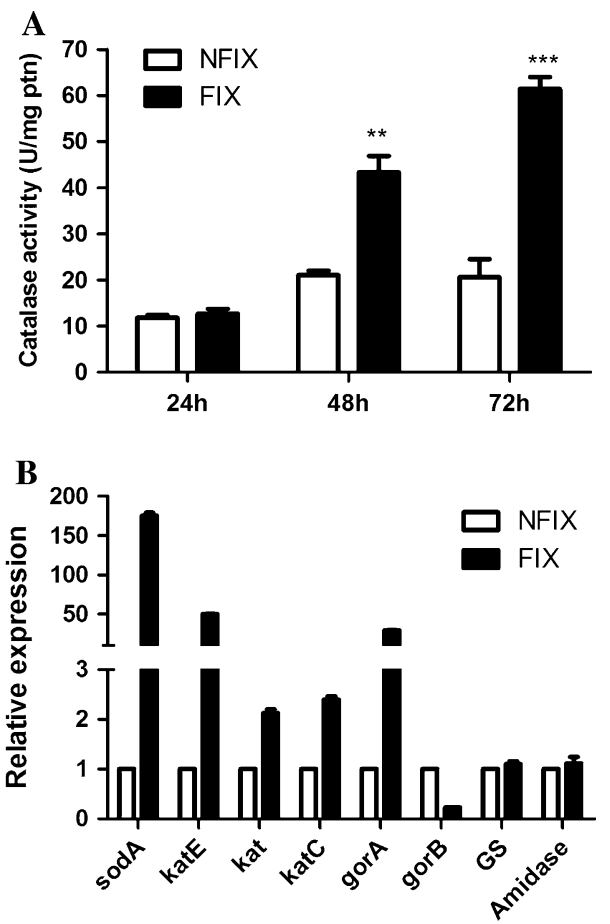

Fig. 2 Expression and activity of ROS detoxification in G. diazotrophicus during nitrogen fixation. a Catalase activity of cells grown in fixing and non-fixing conditions. $\mathbf{b}$ mRNA expression of the genes involved in ROS-detoxification from fixing and non-fixing cells. The data are expressed as the relative expression of the respective mRNAs normalized to the housekeeping gene $23 \mathrm{~S}$. The data are expressed as the average of three replicates \pm error bars

The genes for catalase type $\mathrm{E}(k a t E)$ and superoxide dismutase A ( $\operatorname{sod} A)$ are co-expressed with the $\alpha$-subunit of nitrogenase Mo-Fe protein (nifD)

In order to identify the most relevant ROS-detoxification genes to BNF, we searched for distinct expression patterns (clusters) (D'Haeseleer 2005). Genes were grouped on the basis of their common expressions across time points and indicative of the presence of ROS. All images were acquired with the same exposure time to allow comparison of signal intensities. Scale bar $10 \mu \mathrm{m}$

under nitrogen-fixing and non-nitrogen-fixing conditions (Fig. 3). Cluster analysis separated these genes in two major clusters: one formed by gor $B$ alone and the other formed by gorA, kat, katC, nifD, sodA and katE, with similarities up to $98 \%$ inside this group. Notice that the genes present in this cluster are strongly induced as mentioned earlier (Fig. 2b). This last cluster can be divided into three minor clusters kat + gorA; katC; and katE+ $\operatorname{sodA}+$ nifD. This cluster has $99.8 \%$ similarity and it is stable when we use different algorithms for clustering (single and average linkage, median linkage and ward linkage), suggesting that $\operatorname{sod} A$ and $k a t E$ have a major protective role in the nitrogen fixation process. It is interesting to note that the genes grouped in this cluster have higher similarity to related enzymes from other non-symbiontic closely related subclass Alphaproteobacteria (Table 1), while the other ROS-detoxifying genes analyzed have higher similarity to related enzymes from phylogenetically distant symbiontic organisms. This could be an indication that nitrogen fixation is an ancient process in $G$. diazotrophicus and was probably acquired before the adaptation to the endophytic lifestyle (Bertalan et al. 2009).

The presence of ROS strongly inhibits nitrogen fixation

To further explore differences concerning ROS levels between nitrogen-fixing and non-fixing bacteria, the resistance of G. diazotrophicus to oxidative stress was investigated by the addition of Paraquat (PQ), a redox cycler that increases cellular ROS generation, into the cultures. The growth of nitrogen-fixing cells (Fig. 4a) was severely inhibited by the addition of $\mathrm{PQ}$, indicating that the antioxidant capacity of fixing cells (Fig. 2) is overwhelmed by the pro-oxidant effects of this molecule. On the other hand, non-nitrogen-fixing cells were resistant to both 0.5 and $5 \mathrm{mM}$ of $\mathrm{PQ}$, as they maintained high growth rates and achieved high cell densities (Fig. 4a). General appearance 
Table 1 Identification of antioxidant genes from G. diazotrophicus

\begin{tabular}{|c|c|c|c|c|}
\hline Gene & Locus tag & Product & Conserved domains & Similar to \\
\hline $\operatorname{sod} A$ & GDI2168 & $\begin{array}{l}\text { Superoxide } \\
\text { dismutase }\end{array}$ & $\begin{array}{l}\text { "Iron/manganese sod, C-terminal domain" } \\
\text { "Iron/manganese sod, alpha-hairpin domain" }\end{array}$ & Gluconobacter oxydans (340s, 80\%id) \\
\hline katE & GDI0079 & Catalase HPII & $\begin{array}{l}\text { "KatE" "heme-binding pocket" "tetramer } \\
\text { interface" }\end{array}$ & Chromobacter salexigens $\mathrm{KatE}$ (788s, 74\%id) \\
\hline kat & GDI0467 & Non-heme catalase & "Catalase superfamily" & $\begin{array}{l}\text { Methylobacterium extorquens Kat (332s, } \\
53 \% \text { id) }\end{array}$ \\
\hline katC & GDI2359 & Catalase HPII & “(GATase1)-like" & Azoarcus sp. KatC (1055s, 72\%id) \\
\hline gorA & GDI2216 & $\begin{array}{l}\text { Glutathione } \\
\text { reductase }\end{array}$ & $\begin{array}{l}\text { "Pyridine nucleotide-disulphide oxidoreductase" } \\
\text { "Glutathione reductase" }\end{array}$ & Acetobacter pasteurianus $(664 \mathrm{~s}, 70 \% \mathrm{id})$ \\
\hline gor $B$ & GDI2280 & $\begin{array}{l}\text { Glutathione } \\
\text { reductase }\end{array}$ & $\begin{array}{l}\text { "Pyridine nucleotide-disulphide oxidoreductase" } \\
\text { "HI0933-like protein" }\end{array}$ & Xanthomonas campestris (436s, 63\%id) \\
\hline
\end{tabular}

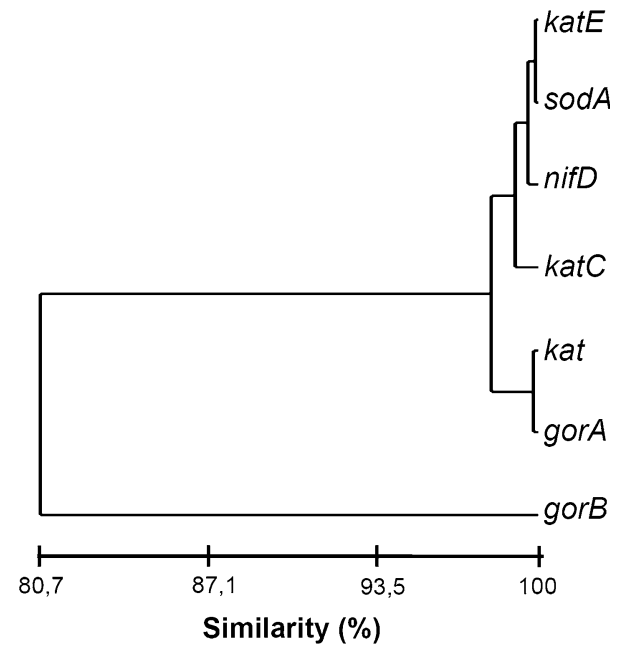

Fig. 3 Cluster analysis of redox genes. Notice that there are two major clusters: one formed by gorB alone and the other formed by gorA, kat, katC, nifD, sodA, and katE, with similarities up to $98 \%$ inside this group. This last cluster can be divided in three minor clusters $k a t+$ gorA, $k a t C$ and $k a t E+\operatorname{sod} A+$ nifD

of cells was similar for all PQ concentrations (data not shown). This data is in accordance with previous results (Figs. 1, 2) and demonstrate the resistance of non-fixing cells to ROS also reveals that fixing cells up-regulate antioxidant pathways (Fig. 2) to lower ROS levels (Fig. 1), a condition that is essential for its survival (Fig. 4a).

To investigate whether BNF suppression was the basis for inhibition of cell growth in the presence of $\mathrm{PQ}$, nitrogenase activity of cultures grown in the presence of PQ was tested by the acetylene reduction essay. Cells grown without PQ were used as a control. PQ was added to the medium after $24 \mathrm{~h}$ of growth and the nitrogenase activity was measured after a further $48 \mathrm{~h}$ (72 h of cultivation). Nitrogenase activity decreased $64 \%$ when $0.5 \mathrm{mM}$ of PQ was added to the medium. When the concentration was changed from 0.5 to $5 \mathrm{mM}$, nitrogenase activity decreased to zero showing that the presence of ROS can strongly
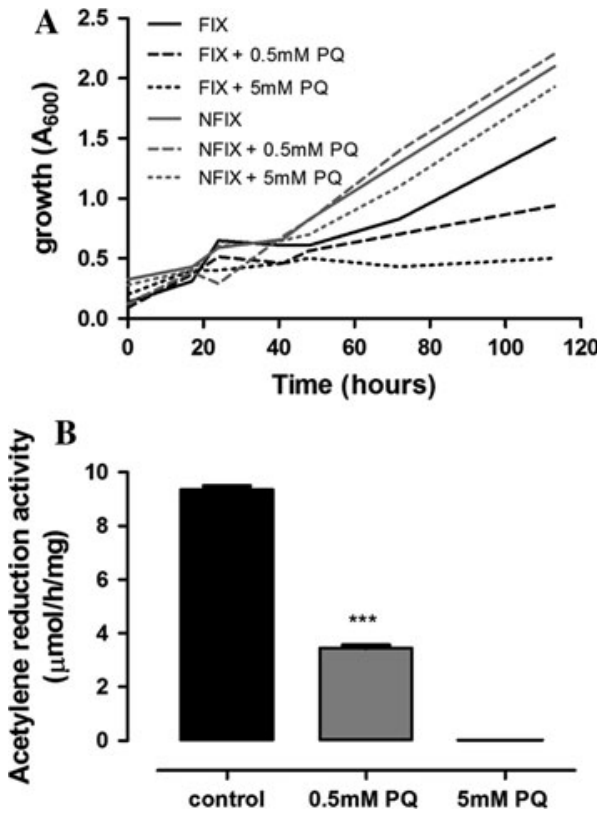

Fig. 4 ROS effect on cell growth and BNF activity. a Effect of different concentrations of PQ on the growth of fixing (black) and non-fixing (gray) cells. After an initial growth period of $24 \mathrm{~h}, \mathrm{PQ}$ was added at a concentration of $0.5 \mathrm{mM}$ or $5 \mathrm{mM}$ (dashed and dotted lines, respectively). b Acetylene reduction activity (ARA) of $G$. diazotrophicus after $72 \mathrm{~h}$ cultivation. The activity was measured after $48 \mathrm{~h}$ in the presence of 0.5 and $5 \mathrm{mM}$ of PQ

inhibit BNF in G. diazotrophicus (Fig. 4b). Therefore, fixing cells up-regulate antioxidant pathways in order to lower ROS levels and preserve nitrogenase activity, placing the regulation of ROS levels as a critical step to allow biological nitrogen fixation.

\section{Discussion}

Here, we demonstrate that antioxidant pathways are upregulated during $\mathrm{BNF}$ to prevent ROS-induced nitrogenase 
inhibition in $G$. diazotriphicus. Organisms that fix nitrogen usually adopt different strategies to protect nitrogenase from contact with $\mathrm{O}_{2}$. The most studied is the Rhizobia strategy that infects the plant and forms nodules that create an anaerobic environment that favors BNF, while the plant supplies the energy requirement for the $\mathrm{N}$-fixing bacteria (Fischer 1994). Differently from Rhizobia, G. diazotriphicus colonizes the intercellular spaces of the plant (apoplastic) and doesn't form nodules and is therefore always exposed to higher levels of $\mathrm{O}_{2}$ (Dong et al. 1994). In fact, optimal nitrogen fixation by $G$. diazotrophicus demands high aerobic conditions both in solid (Pan and Vessey 2001) and liquid cultures (Flores-Encarnacion et al. 1999). However, when oxygen is measured in the liquid phase during BNF, the maximum nitrogenase activity of $G$. diazotrophicus is observed at a $\mathrm{pO}_{2}$ of $0.2 \mathrm{kPa}$ (Reis and Dobereiner 1998). This is an indication that in order to keep the low levels of $\mathrm{O}_{2}$ dissolved in the medium $G$. diazotrophicus adopts the so-called "respiratory protection" strategy. Accordingly, G. diazotrophicus changes its electron transport chain composition during BNF. In this context, well-aerated cultures express cytochrome a1 and cytochrome bb as the main terminal oxidase. During repression of diazotrophic activity, cytochrome a1 diminishes dramatically concomitantly with the appearance of cytochrome bd (Flores-Encarnacion et al. 1999). Oxidase activities are also much higher in membrane preparations obtained from cultures under BNF conditions than in those from cultures under non-nitrogen-fixing conditions and the respiratory rate was among the highest ever reported for aerobic bacteria (Flores-Encarnacion et al. 1999; Gonzalez et al. 2006).

However, an aspect that has been overlooked is the impact of the respiratory protection on ROS generation. Higher respiratory rates may lead to increased production of oxygen radicals (Boveris and Chance 1973), a condition that would favor redox imbalance and consequently oxidative stress. Here, we tried to explore this paradox and incorporate our data into the respiratory protection hypothesis. We propose that in parallel to the increase in aerobic respiration that occurs during BNF, G. diazotrophicus also up-regulate antioxidant pathways to protect nitrogenase from ROS inhibition.

The importance of redox homeostasis to symbiotic BNF process has been indicated by previous studies with Sinorhizobium meliloti strains. Mutants affected in the antioxidant defense did not reach the differentiation stage of nitrogen-fixing bacteroids (Santos et al. 2000; Jamet et al. 2003; Harrison et al. 2005). Similarly, a peroxiredoxin (prxS)/bifunctional catalase-peroxidase (katG) Rhizobium etli double mutant has a significantly reduced symbiotic nitrogen fixation capacity (Dombrecht et al. 2005; for a review see Chang et al. 2009). Still, these effects could be both due to the presence of ROS or due to the incapacity of the bacteria to promote a normal nodule formation and therefore the environment that is necessary to allow nitrogen fixation. Our data show that ROS can directly inhibit nitrogenase activity, and $G$. diazotrophicus alters its redox metabolism during BNF to cope with that.

Concerning our gene analysis, most of the ORFs shared by G. diazotrophicus and other closely associated Alphaproteobacteria are related to energy metabolism and are generally part of the core genome of $G$. diazotrophicus (Bertalan et al. 2009). One interesting aspect of catalase gene analysis (GDI0467 and GDI2359) is that although the most similar sequences are from phylogenetically distant organisms, they were all isolated from plant leaves and have the ability to promote the growth of various plant seedlings (Abanda-Nkpwatt et al. 2006; Sessitsch et al. 2005). This is an indicative that these genes were acquired later, possible by lateral gene transfer. This could be especially important for bacterial adaptation to the endophytic lifestyle and may confer advantages to $G$. diazotrophicus in comparison with other microbes that colonize the same niche.

This study can be regarded as the first step toward understanding of ROS metabolism in Acetobacteraceae. It is also the first characterization of ROS production and modification of the redox state during BNF process. Our main finding is that during BNF G. diazotrophicus activate antioxidant pathways that diminish the intracellular levels of ROS protecting nitrogenase from ROS toxicity. These results complement the respiratory protection hypothesis previously described and allow a better comprehension of nitrogenase activity in aerobic environments.

Acknowledgments This work was supported by CNPq, FINEP, FAPERJ and INCT-FBN.

Open Access This article is distributed under the terms of the Creative Commons Attribution Noncommercial License which permits any noncommercial use, distribution, and reproduction in any medium, provided the original author(s) and source are credited.

\section{References}

Abanda-Nkpwatt D, Musch M, Tschiersch J, Boettner M, Schwab W (2006) Molecular interaction between Methylobacterium extorquens and seedlings: growth promotion, methanol consumption, and localization of the methanol emission site. J Exp Bot 57:4025-4032

Aebi H (1984) Catalase in vitro. Methods Enzymol 105:121-126

Baldani JI, Caruso L, Baldani VLD, Goi SR, Dobereiner J (1997) Recent advances in BNF with non-legume plants. Soil Biol Biochem 29:911-922

Bertalan M, Albano R, de Padua V, Rouws L, Rojas C, Hemerly A, Teixeira K, Schwab S, Araujo J, Oliveira A et al (2009) Complete genome sequence of the sugarcane nitrogen-fixing 
endophyte Gluconacetobacter diazotrophicus Pal5. BMC Genomics 10:450

Boveris A, Chance B (1973) The mitochondrial generation of hydrogen peroxide. General properties and effect of hyperbaric oxygen. Biochem J 134:707-716

Bradford MM (1976) A rapid and sensitive method for the quantitation of microgram quantities of protein utilizing the principle of protein-dye binding. Anal Biochem 72:248-254

Cavalcante VA, Dobereiner J (1988) A new acid-tolerant nitrogenfixing bacterium associated with sugarcane. Plant Soil 108: $23-31$

Chang C, Damiani I, Puppo A, Frendo P (2009) Redox changes during the legume-Rhizobium symbiosis. Mol Plant 2:370-377

D'Haeseleer P (2005) How does gene expression clustering work? Nat Biotechnol 23:1499-1501

Dalton DA (1995) Antioxidant defenses of plants and fungi. Chapman \& Hall, New York

Dalton H, Postgate JR (1968) Effect of oxygen on growth of Azotobacter chroococcum in batch and continuous cultures. J Gen Microbiol 54:463-473

Dombrecht B, Heusdens C, Beullens S, Verreth C, Mulkers E, Proost P, Vanderleyden J, Michiels J (2005) Defence of Rhizobium etli bacteroids against oxidative stress involves a complexly regulated atypical 2-Cys peroxiredoxin. Mol Microbiol 55: $1207-1221$

Dong Z, Canny MJ, McCully ME, Roboredo MR, Cabadilla CF, Ortega E, Rodes R (1994) A nitrogen-fixing endophyte of sugarcane stems (a new role for the apoplast). Plant Physiol 105:1139-1147

Fischer HM (1994) Genetic regulation of nitrogen fixation in rhizobia. Microbiol Rev 58:352-386

Flores-Encarnacion M, Contreras-Zentella M, Soto-Urzua L, Aguilar GR, Baca BE, Escamilla JE (1999) The respiratory system and diazotrophic activity of Acetobacter diazotrophicus PAL5. J Bacteriol 181:6987-6995

Forman HJ, Maiorino M, Ursini F (2010) Signaling functions of reactive oxygen species. Biochemistry 49:835-842

Gonzalez B, Martinez S, Chavez JL, Lee S, Castro NA, Dominguez MA, Gomez S, Contreras ML, Kennedy C, Escamilla JE (2006) Respiratory system of Gluconacetobacter diazotrophicus Pal5. Evidence for a cyanide-sensitive cytochrome bb and cyanideresistant cytochrome ba quinol oxidases. Biochim Biophys Acta 1757:1614-1622

Harrison J, Jamet A, Muglia CI, Van de Sype G, Aguilar OM, Puppo A, Frendo P (2005) Glutathione plays a fundamental role in growth and symbiotic capacity of Sinorhizobium meliloti. J Bacteriol 187:168-174

Hassett DJ, Britigan BE, Svendsen T, Rosen GM, Cohen MS (1987) Bacteria form intracellular free radicals in response to paraquat and streptonigrin. Demonstration of the potency of hydroxyl radical. J Biol Chem 262:13404-13408

Jamet A, Sigaud S, Van de Sype G, Puppo A, Herouart D (2003) Expression of the bacterial catalase genes during Sinorhizobium meliloti-Medicago sativa symbiosis and their crucial role during the infection process. Mol Plant Microbe Interact 16:217-225

Kim J, Rees DC (1994) Nitrogenase and biological nitrogen fixation. Biochemistry 33:389-397

Kowaltowski AJ, de Souza-Pinto NC, Castilho RF, Vercesi AE (2009) Mitochondria and reactive oxygen species. Free Radic Biol Med 47:333-343

Livak KJ, Schmittgen TD (2001) Analysis of relative gene expression data using real-time quantitative PCR and the $2^{-\Delta \Delta \mathrm{Ct}}$ method. Methods 25:402-408

Pan B, Vessey JK (2001) Response of the endophytic diazotroph Gluconacetobacter diazotrophicus on solid media to changes in atmospheric partial $\mathrm{O}_{2}$ pressure. Appl Environ Microbiol 67:4694-4700

Reis VM, Dobereiner J (1998) Effect of high sugar concentration on nitrogenase activity of Acetobacter diazotrophicus. Arch Microbiol 171:13-18

Robson RL, Postgate JR (1980) Oxygen and hydrogen in biological nitrogen fixation. Annu Rev Microbiol 34:183-207

Santos R, Hérouart D, Puppo A, Touati D (2000) Critical protective role of bacterial superoxide dismutase in Rhizobium-legume symbiosis. Mol Microbiol 38:750-759

Sessitsch A, Coenye T, Sturz AV, Vandamme P, Barka EA, Salles JF, Van Elsas JD, Faure D, Reiter B, Glick BR et al (2005) Burkholderia phytofirmans sp. nov., a novel plant-associated bacterium with plant-beneficial properties. Int J Syst Evol Microbiol 55:1187-1192

Sevilla M, Burris RH, Gunapala N, Kennedy C (2001) Comparison of benefit to sugarcane plant growth and $15 \mathrm{~N} 2$ incorporation following inoculation of sterile plants with Acetobacter diazotrophicus wild-type and Nif-mutants strains. Mol Plant Microbe Interact 14:358-366

Terada LS (2006) Specificity in reactive oxidant signaling: think globally, act locally. J Cell Biol 174:615-623

Ureta A, Nordlund S (2002) Evidence for conformational protection of nitrogenase against oxygen in Gluconacetobacter diazotrophicus by a putative FeSII protein. J Bacteriol 184:5805-5809 